\title{
Silk Road Economic Belt Initiative and Inbound Tourism Development in the Uyghur Autonomous Region
}

\author{
Parhad Keyim Idikut \\ Karelian Institute, University of Eastern Finland, Joensuu, Finland \\ Email: parhad.keyim.idikut@uef.fi
}

How to cite this paper: Idikut, P. K. (2020). Silk Road Economic Belt Initiative and Inbound Tourism Development in the Uyghur Autonomous Region. Advances in Applied Sociology, 10, 219-235.

https://doi.org/10.4236/aasoci.2020.106014

Received: May 3, 2020

Accepted: June 7, 2020

Published: June 10, 2020

Copyright $\odot 2020$ by author(s) and Scientific Research Publishing Inc. This work is licensed under the Creative Commons Attribution International License (CC BY 4.0).

http://creativecommons.org/licenses/by/4.0/

\begin{abstract}
The "Silk Road Economic Belt" (SREB) is a land-based component of the "One Belt One Road" initiative that intends to create an economic corridor connecting China with the rest of the Eurasian continent via Central Asia. The aims of the SREB are to stimulate multilateral trade and maintain open border regimes that consequently promote Sino-Central Asia cross-border movements including international tourism. Chinese authority accredited the success of the SREB to long-term stability in the Xinjiang Uyghur Autonomous Region (XUAR). In order to achieve long-term stability, Beijing has determined to fight against the "three evil forces" namely political separatism, Islamist extremism and terrorism. These hardline measures of keeping the regional stability and consequent government policies and regulations towards cross-border tourism, however, hamper the international tourism mobility to the XUAR, which makes inbound tourism development in the XUAR vulnerable and a side issue of the SREB.
\end{abstract}

\section{Keywords}

Silk Road Economic Belt, The Uyghur Autonomous Region, Inbound Tourism, Security, Stability

\section{Introduction}

The "Silk Road Economic Belt" (SREB) is a land-based component of the "One Belt One Road" initiative that intends to create an economic corridor connecting China with the rest of the Eurasian continent. Specifically, the SREB creates an economic corridor between the Xinjiang Uyghur Autonomous Region (XUAR) of China and the Central Asian countries (Kazakhstan, Kyrgyzstan, Uzbekistan, Turkmenistan and Tajikistan) via a land transportation network including 
highways and rail routes, oil and natural gas pipelines as well as power grids. The aims of the SREB are to stimulate multilateral trade and to maintain open border regimes that consequently promote Sino-Central Asia cross-border movements, including international tourism. However, security and stability considerations in the XUAR (the authority's fight against "three evil forces") and in the Central Asian countries (Sinophobia) and consequent government policy and regulation towards tourism (visa, passport) affect the regional international tourism development. Based on a review of the relevant literature, the article will begin by addressing the concept of the SREB and its implication in the XUAR and Central Asia. The paper moves then on to an analysis of official documents and statistics to gauge the possible impacts of the SREB on inbound tourism development in the XUAR.

\section{Contextualizing the SREB in the XUAR and Central Asia}

The SREB is an overland component of China's "One Belt One Road" (OBOR) initiative that also includes a seagoing component called "21st Century Maritime Silk Road". While the "Maritime" initiative aimed at developing China's economic ties along the sea route with multiple players in Southeast Asia, South Asia, and Africa, the SREB aimed at creating an economic corridor through Eurasian continent via land transportation network. On 14 May 2017, Chinese President Xi Jinping pledged $\$ 124$ billion for the OBOR, which he called a "plan to forge a path of peace, inclusiveness and free trade" (Goh \& Chen, 2017).

The literature has addressed the OBOR from various perspectives including economic integration, (geo) political strategy, international and domestic security, and stability maintenance in the XUAR. According to Campbell (2017), the OBOR:

"spans some 65 countries, covering $70 \%$ of the planet's population, three-quarters of its energy resources, a quarter of goods and services and $28 \%$ of global GDP-some $\$ 21$ trillion. By boosting connectivity, China can spur growth in the short term, gain access to valuable natural resources in the mid-term and create new booming markets for its goods long into the future."

To handle the economic slowdown and manufacturing overcapacity in China, the Chinese authority has encouraged domestic firms to build railways, roads and ports in countries located along the OBOR, including the SREB. According to $\mathrm{Yu}$ (2017), Chinese companies have become the main shareholder investing in container ports along the OBOR:

- In Sri Lanka: China Merchants Holdings (international) holds 85\% share of the Colombo International Container Terminal, and China Harbour Engineering Corporation holds 65\% share of the Hambantota Container Port.

- In Myanmar: China National Petroleum Corporation (CNPC) holds 50.9\% share of the Kyaukphyu Port.

- In Singapore: COSCO Pacific holds $49 \%$ share of the Singapore Container 
Port.

- In Malaysia: Guangxi Beibu Gulf Port Group holds 40\% share of the Kuantan Port.

- In Pakistan: China Overseas Port Holding Company has a 40-year lease agreement for operating and managing Gwadar Port.

- In Italy: COSCO Pacific holds 50\% share of the Naples Container Port.

- In Greece: COSCO Pacific has a 35-year lease agreement for operating and managing Piraeus Container Port.

The SREB intends to spur China's export of manufacturing overcapacity in cement, still, aluminium, and rolling stock production, which have suffered from the country's economic slowdown. The economic growth rate of China decreased from $10.5 \%$ in 2010 to $6.9 \%$ in 2015; the lowest since 1990 (Shen \& Chen, 2017). As a result of the economic slowdown, manufacturing capacity utilization decreased from 70\% in 2012 to around 65\% in 2015 (Shen \& Chen, 2017).

China also encourages national energy companies to invest in Central Asia, where they already hold a strong position (Downs, 2015). The CNPC, for example, has established itself as a dominant foreign energy company in Central Asia. The CNPC began construction of a $3666 \mathrm{~km}$ long Central Asia-China gas pipeline in 2007. The pipeline stretches from Turkmenistan to the XUAR via Uzbekistan and Kazakhstan. In 2010 alone, the pipeline transported 4.38 billion cubic metres of natural gas from Turkmenistan to China (Hydrocarbons Technology, 2017).

According to Callahan (2016), Beijing understands the OBOR, including the SREB, as not only a space for win-win economic cooperation but also as a space for the construction of a Sino-centric regional and world order. Hu et al. (2014) argued that the SREB serves China's comprehensive view of national security, i.e. military, economic, regime, and cultural security; international and domestic security, and stability maintenance in the XUAR. Overreliance of Chinese export and import (including energy resources) trades on eastern coastal ports pushes China to implement the SREB. Because the SREB was understood as a Chinese countermeasure towards the maritime American hegemony that prevents China's export and import trades on eastern coastal ports. Besides, " $[t]$ he penetration of the United States into Central Asia not only prevents China from expanding its influence but also sandwiches China from East to West, thus 'effectively containing a rising China"' (Gao, 2002).

The SREB fosters a Sino-Central Asia infrastructure network, which would ensure that "China maintains an economic and, therefore, a political and military stake in the region to secure investments" (Zenn, 2015: p. 9). The construction of a Sino (XUAR)-Kazakhstan cooperation demonstration zone, as part of the SREB, not only has a very important strategic significance for realizing bilateral economic and trade cooperation but also has great significance for strengthening Chinese national economic and defence-security, national unity and social and political stability, especially in the XUAR (Fang et al., 2016). 
To achieve political stability through economic development in the XUAR, the SREB planned various projects in the regional cities including Urumqi, Khorgos, and Kashgar. The SREB planned to construct a Central Asian High-speed Rail that connects Urumqi with cities in Germany via travelling through the territories of Uzbekistan, Turkmenistan, Iran, and Turkey (Huang, 2016). A 270 $\mathrm{km}$-long rail route connecting Kashgar with Andijan (eastern Uzbekistan) via the territory of Kyrgyzstan's Naryn and Osh oblasts was also planned (UK Foreign Office, 2014).

However, state-driven economic development in the XUAR and Chinese engagement with Central Asia, i.e. the SREB and its precursor the Western Development (Xibu dakaifa, in Chinese pinyin) campaign, have widened socio-economic inequality between ethnic minorities and the Han Chinese majority (Roberts, 2016). In the XUAR, employment and income inequalities exist between so-called ethnic minorities (Uyghur, Kazakh, Kyrgyz, and so forth) and the Han ethnic group; inequalities between rural and urban zones also exist (Beydulla, 2012; Cao, 2010; Chaudhuri, 2010; Toops, 2016). The XUAR's ethnic Uyghurs, which make up more than half of the regional population, feel marginalized and even persecuted under Beijing's rule (Campbell, 2017; Rajagopalan, 2017).

Recently, the XUAR entered a state of virtual lockdown due to a sweeping new security regime (Clarke, 2017; Feng, 2017; Rajagopalan, 2017). Uyghurs in the southern XUAR cannot even travel to neighbouring villages without official permission (Campbell, 2017). Newborns are banned from being given Islamic names including Mohammed. Most Uyghurs' passports have been confiscated and banned from travelling abroad.

The crackdown also targets Kazakh residents, including Kazakhstani green card holders who mainly live in northern XUAR bordering Kazakhstan. This is due to the Chinese government's overreaction over the "invasion" of "three evil forces" in its border areas that sharing $3000 \mathrm{~km}$ long borderline with Central Asian countries (Hu et al., 2014). Police in Dorbiljin (Emin), a county located at the XUAR-Kazakhstan border, have detained an estimated 500 Kazakh traders and businesses during raids in November 2017 (Radio Free Asia, 2017a). During another police raid conducted between October 25 and November 1, Chinese authorities in Tekes County (Tekesi), also located not far from the XUAR-Kazakhstan border, have searched the homes of 30,000 members of Kazakh and Uyghur ethnic groups (Radio Free Asia, 2017b). The raid aimed at confiscating copies of the Quran, prayer mats and other religious items.

According to Clarke (2008: p. 96), through the Western Development campaign, which was launched in 1999, the security and stability in the XUAR were to be achieved by economic growth:

"while economic growth was to be assured by the reinforcement of the state's instruments of political and social control, which in turn was to be achieved by opening the region to Central Asia. Importantly, the economic opening to Central Asia would come to offer Beijing a significant element 
of leverage to induce Central Asian states to aid it in its quest to secure Xinjiang against 'separatist' elements."

However, according to Cooley (2015), the SREB and its large-scale investments in the transport network in the XUAR can further fuel the marginalization of the ethnic minorities including the Uyghurs. Roberts (2016: p. 49) also expressed a similar opinion by pointing out that:

“... development of this region over the last quarter century has gradually, but steadily eroded Uyghurs' social capital, destroyed Uyghur cultural landmarks, brought large numbers of Han migrants to the region, forced Uyghurs to change their behaviours and livelihoods and forcibly displaced numerous communities. Furthermore, on-going development in the region continues to have the same impacts, thus further marginalizing the Uyghurs in what they perceive as their historical homeland."

The dynamic relationship between economic development and maintaining stability in the XUAR is further complicated by China's economic and some political engagement with the Central Asian countries since the collapse of the Soviet Union. Among the Central Asian countries, three of them, i.e. Kazakhstan, Kyrgyzstan and Tajikistan, share a common border with the XUAR. Thus, the Central Asian countries are more or less directly affected by the SREB and its precursor, the Western Development campaign of China. The SREB strengthens further the already existing XUAR-Central Asia cross-border integration process that was already promoted by the Western Development campaign. Thanks to those campaigns, the XUAR authorities have upgraded or constructed airports, introduced international and domestic luxurious 5-star hotels, and promoted annual international tourism fairs since 2002. Also, transport facilities, i.e., railways, highways, and oil and gas pipelines that stretch from coastal China to Central Asian Countries were constructed (Keyim, 2017).

By participating in the SREB, the Central Asian Countries aim to benefit from trading with China and receive help to construct and update their energy-related infrastructure and transport networks with the Chinese investment in order to diversify their economy and counterweight the Russian dominance in the region. The Central Asian Countries also aim to benefit from a planned $\$ 4$ trillion Chinese investment through the OBOR (Jelinek, 2017). In September 2013, before a Summit of Shanghai Cooperation Organization (SCO), Central Asian Countries concluded landmark energy and infrastructure deals with China. The SCO was founded in 1996 to demarcate China's borders with its Central Asian neighbours, but it is now also playing an economic role. Thanks to the deals, Kazakhstan received a $\$ 5$ billion stake for the Kashagan oil project in the Caspian Sea. Uzbekistan obtained $\$ 15$ billion worth of investments in the oil, gas and uranium sectors. Kyrgyzstan got a $\$ 3$ billion in energy projects for the 225-kilometer Kyrgyzstan-China gas pipeline to pump gas from "Galkynysh" via Uzbekistan and Kyrgyzstan to the XUAR (Zenn, 2015). China builds a gas pipeline stretching from Turkmenistan to the XUAR that costs US\$7.3 billion (Hol- 
lingsworth, 2017). In 2017 alone, Kazakhstani private businesses opened trade representations in the Chinese cities of Beijing, Shanghai, Guangzhou and Urumqi, and signed deals of exporting processed products that worth $\$ 2.5$ billion (Guliyeva, 2017). China invested US $\$ 1.6$ billion for building an aluminium plant in Tajikistan (Aluminium Insider, 2017).

However, in Tian's (2018: p. 26) words, the Chinese assistance often comes along with "diplomatic conditionality" and "embedded conditionality" in the context of Central Asia. Diplomatic conditionality requires the recipient countries to support "One China" policy, i.e. affirm that the People's Republic of China is the legitimate government of all of China. Central Asian countries have been obligated to support China's crackdown on the "three evil forces" under the frame of the SCOs' Regional Anti-Terror Structure (Pannell, 2011; Zenn, 2015). In return, the Central Asian countries receive generous loans and investments from China (Laruelle, 2018).

Embedded conditionality promotes China's own business interests in Central Asia by requesting the loan recipients to import materials, equipment and technology from China as a precondition of lending loans. Laruelle (2018: p. Xi) argues that these:

"large share of the funds injected by China into Central Asia never leaves the Chinese system: a loan granted by a Chinese bank to a Central Asian government is reinvested in the Chinese company that got the contract, which brings Chinese equipment and a Chinese workforce to Central Asia to carry out the project."

However, Sino-Central Asia cross-border cooperation through the SREB is not always running smoothly. The SREB's aim of promoting a "win-win" situation may not be achieved if local economies gain less benefit from the SREB than large enterprises or political elites who could be exploited by China to get the best deal (Lain, 2018). Kyrgyz government officials and analysts resist the proposed China-Kyrgyzstan-Uzbekistan railroad project because they perceive the SREB to only serve China's own benefit, ignoring the need to resolve the conflicts between ethnic Kyrgyz and Uzbeks in the Fergana valley (Cooley, 2015). Besides, Central Asian countries perceive economic development in the XUAR as a threat, due to the fact that it aims to develop its mineral, energy, food, and textile industries, which are also key sectors for Central Asian states (Lain, 2018). Furthermore, the countries in the region, including Russia, believe that the narrow-gauge rail line extension from China into Central Asia would allow China to quickly mobilize its military forces in the region (Sharip, 2017).

\section{The SREB'S Impact on Inbound Tourism in the XUAR}

International tourism, i.e. both inbound and outbound tourism, involves international mobilities that are subject to evolving (geo) political environments. The (geo) political environment, which includes the national political situation and strategic interests, and consequent national border management policies that 
could affect the movement of people across international boundaries. Kolossov and Scott (2013: p. 9) argue that:

"The crossing and control of borders compete with each other for hegemony: open and more flexible borders are vital for economic reasons, while tighter and more closed borders are seen as important security measures. It is a delicate balance which, in recent years, has swayed towards the securitization proponents because of its emphasis on issues such as personal and physical safety against threats from 'across the border'."

Specifically, international tourism is under the impacts of "the sovereign powers of both the origin and destination state" (Weaver, 2010: p. 48). In the context tourism, state sovereign powers can be exercised in the form of government policy and regulation towards tourism, i.e. visa, passport, transport, and marketing. Thus, the SREB, being a (geo) political gambit in addition to an economic activity (Callahan, 2016; Campbell, 2017; Hu et al., 2014), affects inbound tourism development in the XUAR.

Greater socio-economic and political integration between the XUAR of China and Central Asian countries is expected to promote cross-border tourism in the region (Koh \& Kwok, 2017; Zhong \& Yang, 2015). Through the SREB and its precursor the "Western Development" campaign, the XUAR has promoted cross-border integration with the Central Asian countries by constructing/updating transport networks and tourism infrastructure and enhancing multilateral trade. Urumqi airport, which is one of the five biggest airports in China, and Kashgar airport have been operating scheduled flights that mainly connected to capital cities in the Central Asian countries. Passenger trains from Urumqi were connected to Kazakhstan through Khorgos (Huoerguosi) and Dostyk-Ala Tav (Alashankou) border posts. A sum of 1.4 billion Chinese Yuan has been invested in building a "Silk Road Tourism Distribution Centre" (Sichou zhi lu lüyou jisan zhongxin) in Urumqi (Xinhua Net, 2015). The "Silk Road Tourism Distribution Centre" provides tourism and logistics service, a business center, a hotel, and dining facilities, as well as leisure and entertainment complexes. The planned construction of a free tourism zone in Chöchek Prefecture (Tacheng diqu), which is located at the XUAR-Kazakhstan border, has been seen as the main component of the Sino-Kazakhstan international cooperation demonstration zone (Luo \& Zhang, 2016). The free tourism zone aims to become a well-known destination for Central Asian tourists and an important tourist hub on the SREB. In order to promote the free tourism zone, the implementation of a "three-day visa-free" tourism policy both for Chinese and Kazakhstan nationalities is proposed. It is also proposed to extend a "visa-free" visiting period in the Bakhty free-trade zone (Bianmin hushi maoyiqu), which is a Sino-Kazakhstan border post, from three to fifteen days (Luo \& Zhang, 2016).

In terms of Sino-Central Asia trade, free-trade zones, which mostly been established on the border posts between the XUAR and Kazakhstan, plays a crucial role. The XUAR shares borders with Kazakhstan, Kyrgyzstan and Tajikistan and 
there exist 10 borders crossing stations with these countries (one to Tajikistan, two to Kyrgyzstan, and seven to Kazakhstan) (Table 1). In these free-trade zones at the Sino-Kazakhstan border, Kazakh costumers generally buy Chinese goods that including household appliances, clothing, and decorative building materials, plumbing accessories, handicrafts, knitwear and various fruits. Some Kazakh food and grocery products, as well as other craft products, are also sold at the markets. According to the Hong Kong Trade Development Council (2016: p. 1) "In 2015, Xinjiang's exports to Kazakhstan, Kyrgyzstan and Tajikistan accounted for $62.3 \%, 74.7 \%$ and $76.7 \%$, respectively, of China's exports to these three markets...". The volume of the XUAR-Central Asia bilateral trade increased from 22.29 billion US dollars in 2009 to 46.14 billion US dollars in 2014 (Hong Kong Trade Development Council, 2016).

Free-trade zones have also been established at so-called "Second-class ports" (Erlei kouan), which are mainly located in Urumqi and focus on the wholesale of Chinese goods. Merchants from Wenzhou of Zhejiang province, which is located in coastal China, dominate the wholesale markets in Urumqi. According to an estimation of the Hong Kong Trade Development Council (2016), there were over 100,000 Wenzhou merchants running the wholesale business in the XUAR. In the city of Urumqi, the Bianjiang Hotel International Trade City, the Diwang International Mall, the Dehui Trade City and the Huochetou Foreign Trade Wholesale Market specialise in garments, shoes, headwear and other light industrial goods. The Hualing Comprehensive Market, which gathers about 10,000 businesses from all over China and has an average of around 100,000 daily costumers who generally buy building materials and furniture (Hong Kong Trade Development Council, 2016). Auto parts, tyres and automotive cosmetic products are mainly traded at Xiyu International Trade City.

Table 1. Border crossing posts between the XUAR and central Asian countries.

\begin{tabular}{|c|c|c|}
\hline Name (English/Chinese in pinyin) & Type & Bordering country \\
\hline Urumchi Airport/Wulumuqi feijichang & air & - \\
\hline Kashgar Airport/Kashi feijichang & air & - \\
\hline Kulma-Karasu/Kalasu & road/open to third-country residents & Tajikistan \\
\hline Torugart/Tuergate & road & Kyrgyzstan \\
\hline Irkeshtam/Yierkeshitan & road/open to third-country residents & Kyrgyzstan \\
\hline Narynkol-Muzart/Muzhaerte & road & Kazakhstan \\
\hline Kolzhat-Dulart/Doulata & road & Kazakhstan \\
\hline Khorgos/Horgos & road and railway/open to third-country residents & Kazakhstan \\
\hline Dostyk-Ala Tav/Alashankou & road and railway/open to third-country residents & Kazakhstan \\
\hline Bakhty/Baketu & road/open to third-country residents & Kazakhstan \\
\hline Maikapchagai-Zheminay/Jimunai & road & Kazakhstan \\
\hline Alekseevka-Aheytubiek/Aheitubeke & road & Kazakhstan \\
\hline
\end{tabular}

Source: Keyim, 2017; Tian Shan Net, 2008. 
After gaining independence, Kazakhstan and Kyrgyzstan opened consulates in Urumqi to facilitate the visa process for businesspersons and tourists who were otherwise obliged to travel to Beijing for visa procurement. The year 2017 was announced to be the Year of China's Tourism in Kazakhstan, and the State Tourism Administration of China opened a representative office in Kazakhstan (Mustafayev, 2017). Kazakhstan's Vice Minister of Investment and Development, Timur Toktabaev, stated that "the Chinese market is one of the priorities of Kazakhstan's tourism market” (Atameken, 2017). The Vice Minister also stated that he expected Kazakhstan to receive more Chinese tourists after the opening of the Kazakh section of the "Western Europe-Western China" transport corridor (Atameken, 2017).

Thus, cross-border integration made it possible to facilitate international tourist mobility from Central Asian countries to the XUAR. Free-trade zones have become important visiting destinations for Central Asian tourists, specifically shopping tourists or "shuttle traders". Cross-border shopping tourism refers to people travelling beyond the boundaries of their own country specifically for shopping in a neighbouring country (Timothy, 2005). Price advantages (Timothy, 2005) and "shuttle trade" (Peyrouse, 2008), i.e. intention of reselling the shopped items back home, can also be a driving force for cross-border shopping tourism.

Cross-border shopping tourists from the Central Asian countries began to visit the XUAR just after the breakdown of the Soviet Union. Shopping tourists are mostly unemployed engineers and workers who were left jobless because of the dissolution of the Soviet Union and the collapse of the goods trade from Moscow. There is a divergence in statistical data about shopping tourism. Peyrouse (2008) claims that approximately 700,000 Kazakhstani shopping tourists crossed the Chinese border in 1992 and that shopping tourism provided employment for nearly half a million Kazakhs in 2002. While Peyrouse (2008) also states that more than 3 million people passed through Khorgos border crossing point in 2007, Tian Shan Net (2008) reported that only 493,000 persons crossed the same crossing point, representing $59 \%$ of XUAR's total crossings. However, there is no evidence to support the presumption that they were shopping tourists.

There is a lack of studies on the motivation of inbound tourists in the XUAR and it is not clear whether inbound tourists are mainly composed of shopping tourists. Also, shopping tourism is not classified separately in the statistics of the XUAR. However, between 2014 and 2016, Kazakhstani tourists made up 70.9\% of the total number of inbound tourists in the XUAR on average (The XUAR Tourism Development Board, 2017). Besides, Kazakhstani tourists mainly spent on shopping and long-distance transportation (Xi \& Zhao, 2016). This indicates that Kazakhstani shopping tourists or shuttle traders to the XUAR reflect the inbound tourism development in the region.

On the XUAR side of the Sino-Kazakhstan border, especially in Ili Prefecture (Yili diqu), Uyghur and Dungan shuttle traders have dominated the market in 
the early 1990s (Peyrouse, 2007). However, from the second half of the 1990s onwards, ethnic Han Chinese from the coastal provinces replaced them, especially the Uyghurs. Uyghurs have been further marginalized from cross-border economic activities since the authorities' crackdown after the Ghulja incident in February 1997 (Davis, 2008), a series of demonstrations in the city of Ghulja ( $Y i_{-}$ li) against the Chinese government's attempts to eliminate traditional Uyghur culture.

Except the Narynkol-Muzart and Alekseevka-Aheytubiek border posts at the Sino-Kazakhstan border, there are also some statistics on import-export trade and border crossing activities including the shopping tourism concerning the other Sino-Kazakhstan cross-border posts and nearby free-trade zones:

- Kolzhat-Dulart border post: From 2015 to 2016, import-export trade value increased by $85 \%$; the number of border-crossing reached 29 thousand persons in 2016 that increased by $42.3 \%$ than the year of 2015 (Xinhua Net, 2017).

- Dostyk-Ala Tav border post: In December 2012, Chinese government upgraded the border post and surrounding area to a city named Alashankou that received 15,800 tourists in the first half of the 2017 (Su, 2017) though it was not mentioned what was the portion of the inbound tourists.

- The Bakhty border post: It has become the first "three-day visa-free" (Sanri mianqian) tourism pilot post of the XUAR. In 2013, it hosted 6162 tourists from Kazakhstan who are allowed to touring and shopping in the border city of Chöchek (Ta cheng) located nearby the Bakhty border post (Sohu, 2013). From January to October of 2016, 17 thousand Kazakhstani shopping tourists visited the city of Chöchek (Ministry of Commerce People's Republic of China, 2016).

- Maikapchagai-Zheminay free-trade zone: Traders are allowed to visit the market as a one-day trip without a visa (Tian Shan Net, 2008). The free-trade zone was relocated to Jimunai County and held an opening ceremony on December 3, 2008. On the same day, 263 Kazakhstani citizens visited the market and purchased a 1.45 million Chinese Yuan worth of goods (Zhao \& Xiao, 2008). However, from January to August 2017, compared to the same period of the year of 2016, the opened days (75 days) of the free-trade zone was reduced by $27.2 \%$. The total number of visitors (950 persons) was reduced by 63.2\%; the value of the Kazakh goods brought to the market (about 1.6 million Chinese Yuan) was reduced by $66.7 \%$; the value of Chinese goods (288 thousand Chinese Yuan) sold to the Kazakhstani tourists was reduced by $49.8 \%$ (Jimunai County People's Government, 2017).

Kulma-Karasu, which is the only border post between China and Tajikistan, and Torugart and Irkeshtam border posts between China and Kyrgyzstan are located not far from the ancient Silk Road city of Kashgar. The aboriginal people of the XUAR, namely Uyghurs, are mostly centred in Kashgar city and surrounding areas. Here, the Uyghur culture and identity are relatively well 
preserved as compared to other parts of the XUAR, although cultural identity has been suffering from the Chinese authorities' systematic destruction (Roberts, 2016). Along with the Khorgos Special Economic Zones (SEZ), the Chinese government also established an SEZ in Kashgar in 2010 (Chou \& Ding, 2015). The SEZ is a component of the OBOR that aims at "narrowing regional disparity, reducing ethnic tensions, fighting terrorism and balancing US pivot to Asia" (Chou \& Ding, 2015: p. 118). However, Chou and Ding (2015) are sceptical about the aims of the SEZ. Because it "did not address the roots of ethnic tension, including suppression of cultural autonomy and unequal distribution of the benefits and social costs of economic growth" (Chou \& Ding, 2015: p. 118).

The Kulma-Karasu border crossing station at the Sino-Tajikistan border was established in 2004 and upgraded from a seasonal crossing to being open all year round in 2016. The number of border crossings has increased from 8060 persons in 2008 to 16,051 persons in 2013 (Pan \& Liu, 2014). It is not clear whether the people crossing the post were shopping tourists, but a free-trade zone that was established in 2006 at the border post was not successful.

Torugart border post was established in April 1950 during Soviet times (Zhao, 2014). In that time, a great number of production materials and living supplies that urgently needed in the XUAR was imported through this border station. This has made a historic contribution to the stability and development of XUAR. The border post was closed in the second half of 1960 when the Sino-Soviet relations are deteriorated. However, it was re-opened in December 1983. From 1978 to 2013 , over one million persons crossed the border at this station in total. In 2014, about 5000 tourists used the border crossing station, an increase of $21.8 \%$ compared to 2013. The Irkeshtam border crossing station was established in July 1997 (China News, 2016). The border crossing station was used by 30,000 tourists in the first ten months of 2016, but the portion of the inbound tourists is not mentioned.

In general, as a result of processes of cross-border integration, the number of inbound tourists to the XUAR increased from 204,000 persons in 1995 to 2 million in 2016 (Figure 1). However, between the years of 1995 and 2016, inbound tourists only comprised on average $2.7 \%$ of the total number of tourists to the XUAR. This means that tourism in the XUAR mainly depends on tourists mostly originating from China. The market share of inbound tourists in the whole tourism market of the XUAR decreased from 3.8\% during its peak in 1995 to $1.7 \%$ in 2003 . The drop in inbound tourism in 2003 may be due to the severe acute respiratory syndrome (SARS) that broke out in China during that year. The share of inbound tourism again increased to $2.5 \%$ in 2004, but then decreased to $1.7 \%$ in 2009 when the political instability of the XUAR emerged during the Urumqi riots in the capital city of the region (Israeli, 2010). The number of inbound tourists again increased to $3.4 \%$ in 2010, but after that, it has been decreasing even after the SREB was officially launched in 2013 that supposed to promote the inbound tourism in the XUAR. 
Domestic and inbound tourism development in the XUAR

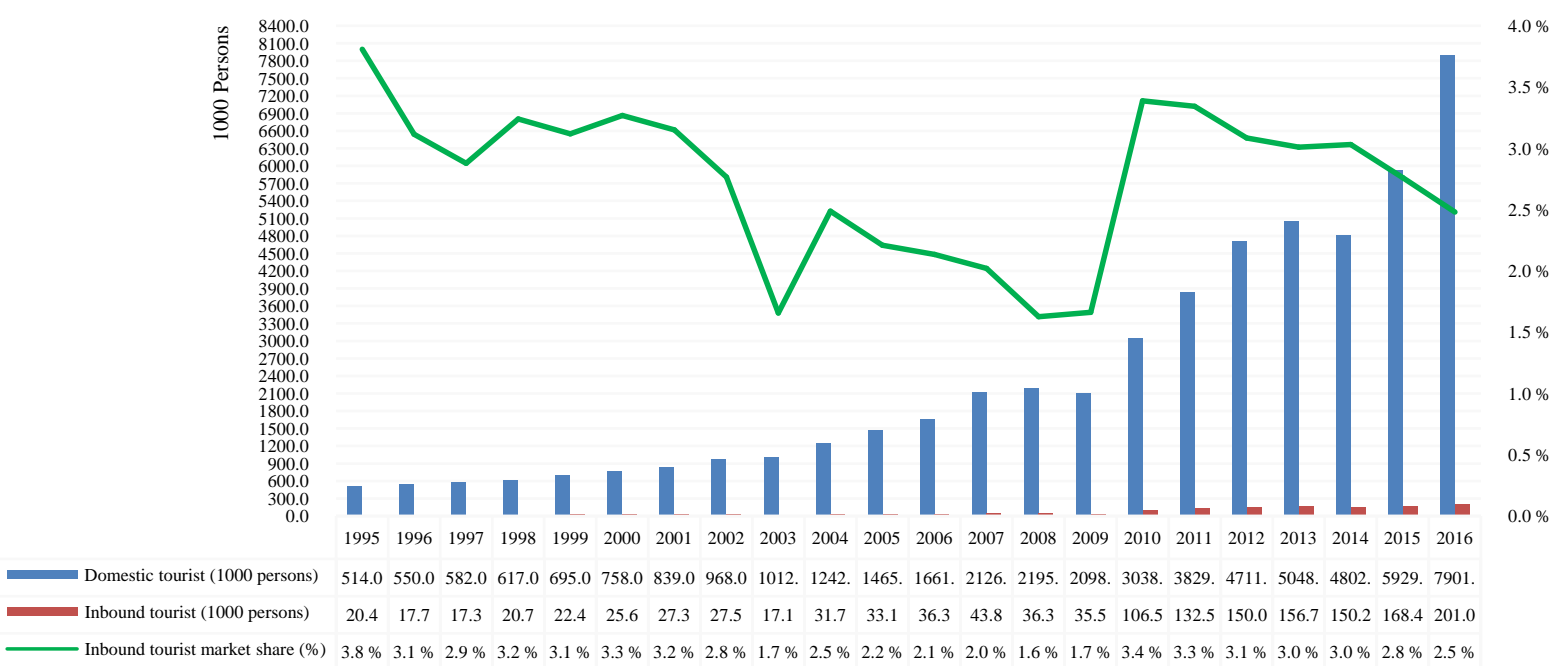

Figure 1. Domestic and inbound tourism development in the XUAR. Source: The XUAR Tourism Development Board, various years. Statistical Bureau of the XUAR, various years.

Among the Central Asian countries, Kazakhstan has become the main inbound tourism market for the XUAR. Between 2013 and 2016, on average, Kazakhstani tourists made up $67.6 \%$ of the total inbound tourism market in the XUAR (The XUAR Tourism Development Board, 2017). Kazakhstani tourists' market share in the entire inbound tourism market of XUAR increased from $54.2 \%$ in 2013 to $75.5 \%$ in 2015, but the volume decreased to $70.6 \%$ in 2016 .

The above findings suggest that inbound tourism development in the XUAR has not been necessarily benefiting from the SREB. Improved transport links between the XUAR and Central Asian countries alone might not promote regional tourism development. The (geo) political issues, i.e. the so-called "three evil forces" in the XUAR and the Chinese authorities' consequent hard-line approach in the region can result in policies and regulation that are unfavourable to regional inbound tourism development. Scholars (Yang \& Yan, 1999) suggested visa-free travel between the XUAR and Central Asian countries almost two decades ago. Zhong and Yang (2015) also suggested visa-free travels for group tourists, which are easier for monitoring. However, the Chinese authorities have not accepted these suggestions, although Kazakhstani group tourists are allowed to travel without a visa to Sanya city in Hainan province; located in coastal China (Xi \& Zhao, 2016). Besides, the unstable geopolitical and geo-economic situations in Central Asian countries have pushed the Chinese government to integrate the XUAR with coastal China rather than with Central Asia (Su, 2013). There are interstate rivalries among the Central Asian countries, which are rooted in territorial disputes and competition for scarce water resources (Blank, 2012; Nourzhanov, 2009). These countries usually uphold nationalistic and economic protectionism policies, and a non-collaborative posi- 
tion in mutual economic relationships (Spechler, 2002).

From the XUAR and Chinese statistical sources, one cannot find the statics for inbound tourism from Kyrgyzstan, Tajikistan, Uzbekistan and Turkmenistan, which is presumably due to the negligible number of tourists who are visiting the XUAR from these countries. However, Kazakhstan has become both the largest trading partner and inbound tourism market of the XUAR, which is presumably due to the country's gradually strengthened and stabilized socio-economic and political conditions.

\section{Conclusion}

The research findings partially suggest that the SREB selectively promotes processes of cross-border integration, which includes international tourism, between the XUAR and Central Asian countries. The selectivity concerning cross-border integration applies to the Chinese government's preference for cross-border cargo trade over cross-national tourism, China-oriented XUAR domestic tourism over international (inbound) tourism, and Kazakhstan over the other Central Asian countries. Overemphasis on regional security and stability in the XUAR, and highly securitize the Sino-Central Asian border, i.e. so-called fighting against the "three evil forces", may safeguard China's economic corridor connecting the country with the rest of Eurasia via Central Asia. This, however, hampers tourists' mobility and makes inbound tourism development in the XUAR vulnerable and a side issue of the SREB. The promotion of cross-border tourism between the XUAR and Central Asian countries may not be at the top of the Chinese state agenda. Among the Central Asian countries, Kazakhstan has become both the largest trade partner and inbound tourism market of the XUAR. This is presumably due to Kazakhstan's gradually strengthened and stabilized socioeconomic and political conditions that comply with the SREB's preference for cross-border integration that based on the precondition of the enhanced cross-border security. However, we need to mention that this study is not enough to explain China's, through SREB, selective approach concerning cross-border integration between the XUAR and Central Asian countries. Further empirical and theoretical research, specifically from the perspective of Central Asian countries, on the topic, will enhance the findings of this study.

\section{Acknowledgements}

The author thanks the Academy of Finland funded project "The Transformation of the Soviet Republic Borders to International Borders” (2016-2019) for its financial support.

\section{Conflicts of Interest}

The author declares no conflicts of interest regarding the publication of this paper. 


\section{References}

Aluminium Insider (2017). China to Partner with Tajikistan on US \$1.6 Billion Aluminium Plant. Aluminium Insider, November 20.

https://aluminiuminsider.com/china-partner-tajikistan-us1-6-billion-aluminium-plant

Atameken (2017). 2017 Will Be the Year of China Tourism in Kazakhstan. Atameken, September 28, 2016.

http://atameken.kz/en/news/24141-0-god-stanet-godom-turizma-knr-v-kazahstane

Beydulla, M. (2012). Rural Economy, Environmental Degradation and Economic Disparity: A Case Study in Deryabuyi, Xinjiang. Central Asian Survey, 31, 193-207. https://doi.org/10.1080/02634937.2012.671991

Blank, S. (2012). Whither the New Great Game in Central Asia? Journal of Eurasian Studies, 3, 147-160. https://doi.org/10.1016/j.euras.2012.03.005

Callahan, W. A. (2016). China's “Asia Dream" the Belt Road Initiative and the New Regional Order. Asian Journal of Comparative Politics, 1, 226-243. https://doi.org/10.1177/2057891116647806

Campbell, C. (2017). Ports, Pipelines, and Geopolitics: China's New Silk Road Is a Challenge for Washington. Time, October 26.

https://time.com/4992103/china-silk-road-belt-xi-jinping-khorgos-kazakhstan-infrastr ucture/

Cao, H. (2010). Urban-Rural Income Disparity and Urbanization: What Is the Role of the Spatial Distribution of Ethnic Groups? A Case Study of Xinjiang Uyghur Autonomous Region in Western China. Regional Studies, 44, 965-982. https://doi.org/10.1080/00343400903401550

Chaudhuri, D. (2010). Minority Economy in Xinjiang-A Source of Uyghur Resentment. China Report, 46, 9-27. https://doi.org/10.1177/000944551004600102

China News (2016). There Is a Long Queue of Automobiles at the Irkeshtam Post, and Border Clearance Can Be Done in Three Minutes. China News, December 12, 2016. http://www.chinanews.com/cj/2016/12-12/8091510.shtml

Chou, B., \& Ding, X. (2015). A Comparative Analysis of Shenzhen and Kashgar in Development as Special Economic Zones. East Asia, 32, 117-136. https://doi.org/10.1007/s12140-015-9235-5

Clarke, M. (2008). China's Integration of Xinjiang with Central Asia: Securing a "Silk Road" to Great Power Status? China and Eurasia Forum Quarterly, 6, 89-111.

Clarke, M. (2017). Why Xi Jinping's Belt and Road Rhetoric of Inclusion Rings Hollow among the Muslim Uygurs of Xinjiang. South China Morning Post, June 7. http://www.scmp.com/comment/insight-opinion/article/2097229/why-xi-jinpings-beltand-road-rhetoric-inclusion-rings

Cooley, A. (2015). New Silk Route or Developmental Cul-de-Sac? PONARS Eurasian Policy Memo, 372, 1-7.

Davis, E. V. W. (2008). Uyghur Muslim Ethnic Separatism in Xinjiang, China. Asian Affairs: An American Review, 35, 15-30. https://doi.org/10.3200/AAFS.35.1.15-30

Downs, E. (2015). Mission Mostly Accomplished: China's Energy Trade and Investment along the Silk Road Economic Belt. China Brief, 15, 3-6.

Fang, C., He, L., \& Wang, Y. (2016). Strategic Thought and Focus of Sino-Kazakhstan International Cooperation Demonstration Zone in Silk Road Economic Belt. Arid Land Geography, 39, 925-934.

Feng, E. (2017). Security Clampdown Bites in China's Xinjiang Region. Financial Times, November 14. https://www.ft.com/content/ee28e156-992e-11e7-a652-cde3f882dd7b 
Gao, F. Q. (2002). The Real Purpose of the American March into Central Asia. Liaowang Magazine, May 10, 2002. http://www.uscc.gov

Goh, B., \& Chen, Y. (2017). China Pledges \$124 Billion for New Silk Road as a Champion of Globalization. Reuters, May 14. http://www.reuters.com/article/us-china-silkroad-africa-idUSKBN18A02I

Guliyeva, N. (2017). Kazakhstan Trade Houses Opened in China. Baku: Trend News Agency, November 21. https://en.trend.az/business/economy/2824089.html

Hollingsworth, J. (2017). The Centrepieces and Setbacks along China's New Silk Road. South China Morning Post, May 10. http://www.scmp.com/news/china/diplomacy-defence/article/2093654/centrepieces-an d-setbacks-along-chinas-new-silk-road

Hong Kong Trade Development Council (2016). A Belt and Road Development Story: Trade between Xinjiang and Central Asia. Hong Kong: Hong Kong Trade Development Council, March 8, 2016.

http://economists-pick-research.hktdc.com/business-news/article/Research-Articles/ABelt-and-Road-Development-Story-Trade-between-Xinjiang-and-Central-Asia/rp/en/1 /1X000000/1X0A5F0R.htm

Hu, A. G., Ma, W., \& Yan, Y. (2014). Connotation, Definition and Passage of "Silk-Road Economic Belt” Strategy. Journal of Xinjiang Normal University, 35, 1-10.

Huang, Y. (2016). Understanding China’s Belt \& Road Initiative: Motivation, Framework and Assessment. China Economic Review, 40, 314-321. https://doi.org/10.1016/j.chieco.2016.07.007

Hydrocarbons Technology (2017). Central Asia-China Gas Pipeline, Turkmenistan to China. Hydrocarbons Technology, October 13, 2017. https://www.hydrocarbons-technology.com/projects/centralasiachinagasp

Israeli, R. (2010). China's Uyghur Problem. Israel Journal of Foreign Affairs, 4, 89-101. https://doi.org/10.1080/23739770.2010.11446403

Jelinek, T. (2017). How Can the Potential of B\&R Be Fully Realized? Global Times, November 14. http://www.globaltimes.cn/content/1075194.shtml

Jimunai County People's Government (2017). Trade Statistics of the Jimunai Border Free-Trade Zone. Jimunai County People’s Government, September 7, 2017.

Keyim, P. (2017). Inbound Tourism Development at the Western Border Region of China. East Asia, 34, 79-85. https://doi.org/10.1007/s12140-017-9266-1

Koh, S. G., \& Kwok, A. O. (2017). Regional Integration in Central Asia: Rediscovering the Silk Road. Tourism Management Perspectives, 22, 64-66. https://doi.org/10.1016/j.tmp.2017.01.002

Kolossov, V., \& Scott, J. (2013). Selected Conceptual Issues in Border Studies. Belgeo: Revue belge de géographie, 1, 2-16. https://doi.org/10.4000/belgeo.10532

Lain, S. (2018). The Potential and Pitfalls of Connectivity along the Silk Road Economic Belt. In M. Laruelle (Ed.), China's Belt and Road Initiative and Its Impact in Central Asia, Central Asia Program (pp. 1-10). Washington DC: The George Washington University.

Laruelle, M. (2018). Introduction. China's Belt and Road Initiative. Quo Vadis. In M. Laruelle (Ed.), China's Belt and Road Initiative and Its Impact in Central Asia, Central Asia Program (pp. 10-12). Washington DC: The George Washington University.

Luo, Li, G. D., \& Zhang, Q. (2016). Development of Border Tourism and Construction of Free Tourism Zone in Sino-Kazakhstan International Cooperation Demonstration Zone in Silk Road Economic Belt. Arid Land Geography, 39, 959-966. 
Ministry of Commerce People's Republic of China (2016). Border Trade Is Booming at the Bakhty Free-Trade Zone. Beijing: Ministry of Commerce People's Republic of China, November 23, 2016.

http://www.mofcom.gov.cn/article/difang/201611/20161101888182.shtml

Mustafayev, A. (2017). Kazakhstan, China Improve Tourism Co-Op. AzerNews, November 18. https://en.trend.az/casia/kazakhstan/2822920.html

Nourzhanov, K. (2009). Changing Security Threat Perceptions in Central Asia. Australian Journal of International Affairs, 63, 85-104. https://doi.org/10.1080/10357710802666133

Pan, D., \& Liu, Q. F. (2014). Pivot Point of Rising-The Karasu Border Post. Yaxin News, August 16, 2014. http://news.sina.com.cn/c/2014-08-16/053230693923.shtml

Pannell, C. W. (2011). China Gazes West: Xinjiang's Growing Rendezvous with Central Asia. Eurasian Geography and Economics, 52, 105-118. https://doi.org/10.2747/1539-7216.52.1.105

Peyrouse, S. (2007). Economic Aspects of the Chinese-Central Asia Rapprochement. Silk Road Studies Program, Uppsala: Uppsala University.

Peyrouse, S. (2008). Chinese Economic Presence in Kazakhstan: China's Resolve and Central Asia's Apprehension. China Perspectives, 3, 34-49.

https://doi.org/10.4000/chinaperspectives.4053

Radio Free Asia (2017a). China Carries Out "Mass Detentions" of Ethnic Kazakhs in Xinjiang. Radio Free Asia, November 13.

https://www.rfa.org/english/news/uyghur/kazaks-arrests-11132017130345.html

Radio Free Asia (2017b). Police in China's Xinjiang Raid Thousands of Muslim Kazakh Homes. Radio Free Asia, November 16.

Rajagopalan, M. (2017). This Is What a 21st-Century Police State Really Looks Like. BuzzFeed News, October 18.

https://www.buzzfeed.com/meghara/the-police-state-of-the-future-is-already-here?utm term=.ac1xBDkYeB\#.gd75Jb0Y2J

Roberts, S. (2016). Development with Chinese Characteristics in Xinjiang: A Solution to Ethnic Tension or Part of the Problem? In M. Clarke, \& D. Smith (Eds.), China's Frontier Regions: Ethnicity, Economic Integration and Foreign Relations (pp. 22-55). London: I. B. Tauris. https://doi.org/10.5040/9781350985711.ch-001

Sharip, F. (2017). Controversial Railway Project Consolidates China's Foothold in Central Asia. Eurasia Daily Monitor, 14.

Shen, G., \& Chen, B. (2017). Zombie Firms and Over-Capacity in Chinese Manufacturing. China Economic Review, 44, 327-342. https://doi.org/10.1016/j.chieco.2017.05.008

Sohu (2013). Tacheng Became the First Border Tourist City in Xinjiang. Sohu, September 4, 2013. http://roll.sohu.com/20130904/n385890880.shtml

Spechler, M. C. (2002). Regional Cooperation in Central Asia. Problems of Post-Communism, 49, 42-47. https://doi.org/10.1080/10758216.2002.11656011

Su, S. Y. (2017). Alashankou Actively Promote a Strategy of Developing the Bortala Mongol Autonomous Prefecture through Border Post Economy and Rapidly Develop the "Silk Road Economy". China Financial Securities Daily, October 11, 2011. http://news.ifeng.com/a/20171015/52638411 0.shtml

$\mathrm{Su}, \mathrm{X}$. (2013). From Frontier to Bridgehead: Cross-Border Regions and the Experience of Yunnan, China. International Journal of Urban and Regional Research, 37, 1213-1232. https://doi.org/10.1111/j.1468-2427.2012.01191.x

The XUAR Tourism Development Board (2017). http://wlt.xinjiang.gov.cn/ 
Tian Shan Net (2008). Xinjiang Border Crossings Outline. Tian Shan Net, September 8, 2008. http://www.ts.cn/

Tian, H. (2018). China's Conditional Aid and Its Impact in Central Asia. In M. Laruelle (Ed.), China's Belt and Road Initiative and Its Impact in Central Asia, Central Asia Program (pp. 21-33). Washington DC: The George Washington University.

Timothy, D. J. (2005). Shopping Tourism, Retailing, and Leisure. Clevedon: Channel View Publications. https://doi.org/10.21832/9781873150610

Toops, S. (2016). Reflections on China's Belt and Road Initiative. Area Development and Policy, 1, 352-360. https://doi.org/10.1080/23792949.2016.1233072

UK Foreign Office (2014). The China-Kyrgyzstan-Uzbekistan Railway Project. UK Foreign Office, June 5, 2014.

https://www.gov.uk/government/publications/the-china-kyrgyzstan-uzbekistan-railwa y-project

Weaver, D. B. (2010). Geopolitical Dimensions of Sustainable Tourism. Tourism Recreation Research, 35, 47-53. https://doi.org/10.1080/02508281.2010.11081618

Xi, Y., \& Zhao, Q. (2016). Analysis of the Characteristics and Expansion of Kazakhstan Visiting China Market. World Regional Studies, 25, 125-132.

Xinhua Net (2015). The XUAR to Construct a "Silk Road Tourism Distribution Centre". Xinhua Net, May 1, 2015. http://www.xinhuanet.com/politics/2015-05/01/c 1115153305.htm

Xinhua Net (2017). "Grassland Border Pas" Growths through the "One Belt One Road". Xinhua Net, May 13, 2017.

http://www.xinhuanet.com/world/2017-05/13/c 1120965776.htm

Yang, Z., \& Yan, S. (1999). A Preliminary Study on the Sustainable Development of the Tourist in Xinjiang. Arid Land Geography, 22, 27-33.

$\mathrm{Yu}$, H. (2017). Motivation behind China's “One Belt, One Road” Initiatives and Establishment of the Asian Infrastructure Investment Bank. Journal of Contemporary China, 26, 353-368. https://doi.org/10.1080/10670564.2016.1245894

Zenn, J. (2015). Future Scenarios on the New Silk Road: Security, Strategy, and the SCO. Jamestown Foundation China Brief, 15, 9-12.

Zhao, H. Y., \& Xiao, Z. Y. (2008). The Jimunai Free-Trade Zone Is Relocated to a New Site, and the Trade Value Reached 1.45 Million Chinese Yuan on the Same Day. Xinjiang Daily, December 6, 2008. http://www.xjdaily.com/

Zhao, Y. (2014). Traveling in the Border Posts of the XUAR: Torugart Post. Yaxin News, August 19, 2014. http://news.iyaxin.com/content/2014-08/19/content 4650997.htm

Zhong, L., \& Yang, W. (2015). Regional Cooperation System Construction and Research of China's Central Asian International Tourist Area in the Background of the Silk Road Economic Belt. Development of Research, No. 3, 22-26. 